\title{
Rapid Symptomatic Improvement in Gefitinib-Treated Patients with EGFR-Mutated Lung Cancer: Possible Role of Downregulation of Inflammatory Molecules?
}

\author{
Evgeny N. Suspitsin ${ }^{a, b}$ Evgeny V. Levchenko ${ }^{a}$ Fedor V. Moiseyenko ${ }^{a}$ Alexandr O. Ivantsov \\ Samira A. Radzhabova ${ }^{a}$ Dmitry E. Matsko ${ }^{a}$ Vladimir M. Moiseyenko ${ }^{c}$ Evgeny N. Imyanitov ${ }^{a, b, c}$
}

${ }^{a}$ N.N. Petrov Institute of Oncology, St.-Petersburg, ${ }^{b}$ St.-Petersburg Pediatric Medical Academy,

'St.-Petersburg Medical Academy for Postgraduate Studies, Russia

\section{Keywords}

EGFR · Mutation · Gefitinib · Erlotinib · Inflammation · Lung cancer

The tyrosine kinase inhibitors (TKI) of the epidermal growth factor receptor (EGFR), gefitinib (Iressa ${ }^{\mathrm{TM}}$, AstraZeneca, Wedel, Germany) or erlotinib (Tarceva ${ }^{\circledR}$, Roche Pharma AG, Grenzach-Whylen, Germany), induce reduction of tumor size in virtually all patients with advanced non-small cell lung cancer (NSCLC), whose tumors harbor a sensitizing mutation in the EGFR gene $[1,2]$. It has been repeatedly noticed that while the shrinking of the tumor occurs in a gradual manner, the majority of responders demonstrate dramatic symptomatic relief within the very first days or even hours of treatment [3]. This immediate improvement cannot be explained simply by reduction of the tumor mass, therefore other mechanisms have to be considered. Peritumoral inflammation may significantly contribute to the discomfort experienced by cancer patients. In vitro studies demonstrate that EGFR activation is associated with induction of a variety of proinflammatory molecules (e.g., IL6, IL8, ICAM1), and this effect is reversed upon administration of EGFR-specific inhibitors [4-6]. Here we present the results of a comparative analysis of pre- and post-treatment tumor samples from a patient who was diagnosed with EGFR-mutated NSCLC and received gefitinib before surgery.

A 44-year-old female patient was referred to the N.N. Petrov Institute of Oncology with complaints of hemoptysis, fatigue, incapacitating edema of the lower extremities, arthralgy and fever (ECOG status 2-3). Standard X-ray examination and computed tomography (CT) scan of her chest revealed a tumor in the lower lobe of the right lung accompanied by the involvement of hilar and bifurcational lymph nodes (stage T2N2M0/IIIA); no extrapulmonary lesions were identified upon appropriate diagnostic procedures. The affected tissue was obtained by bronchoscopy, and the morphological analysis classified the tumor as adenocarcinoma. A subsequent EGFR mutation test revealed a canonical TKI-sensitizing deletion located within exon 19 of the gene. Given the poor performance status of the patient, the extensive local tumor spread and the presence of a highly predictive EGFR mutation, immediate surgical intervention was considered unreasonable. Instead, neoadjuvant therapy with gefitinib (250 mg daily) was initiated. In addition, hemostatic treatment with etamsylate (250 mg by intramuscular injection, 3 times daily) was performed for 3 days. The prescribed therapy led to rapid symptomatic relief: by day 4, the ECOG status reached 1 , and no signs of hemoptysis or paraneoplastic edema were observed. X-ray and CT examinations were repeated on day 12 of gefitinib therapy. A dramatic reduction of the primary tumor and hilar lymph nodes as well as disappearance of the bifurcational lesions were detected (fig. 1); given the significant downstaging of the disease and good performance status of the patient, a right pneumonectomy with systematic ipsilateral mediastinal lymph node dissection was performed 2 days later.

Both pre- and post-treatment tissue samples contained a sufficient number of neoplastic cells, therefore it was possible to microdissect tumor tissues, isolate RNA, and perform reverse transcription polymerase chain reaction (RT-PCR) expression analysis of a few candidate genes. In addition to the above mentioned EGFR-inducible inflammatory molecules (IL6, IL8, ICAM1), we also considered the TNF-alpha and IL1-beta genes. Both these cytokines contribute to the mobilization of immune cells. TNF-alpha is involved in the formation of peritumoral pleural effusion [7]. A specific haplotype of the IL1-beta was shown to be associated with increased gene expression and elevated lung cancer risk [8]. As a control, we deliberately included in the study 2 genes, which are not related to inflammatory reactions, DPD and ERCC1.

\section{KARGER}

Fax +497614520714

Information@Karger.de

www.karger.com (c) 2011 S. Karger GmbH, Freiburg

$0378-584 \mathrm{X} / 11 / 3410-0559 \$ 38.00 / 0$

Accessible online at:

www.karger.com/onk
Prof. Evgeny N. Imyanitov

Laboratory of Molecular Oncology

N.N. Petrov Institute of Oncology

Pesochny-2, 197758 St.-Petersburg, Russia

Tel. +7 812 59689-51, Fax -47

evgeny@imyanitov.spb.ru 
Quantitative real-time PCR was performed as described in [9]. mRNA expression analysis revealed that the TNF-alpha, IL1-beta and IL8 genes were evidently downregulated during gefitinib therapy (table 1, fig. 1). The IL6 transcript was not seen at all in the pre-treatment sample and was only barely detectable after exposure to the EGFR inhibitor. The expres-

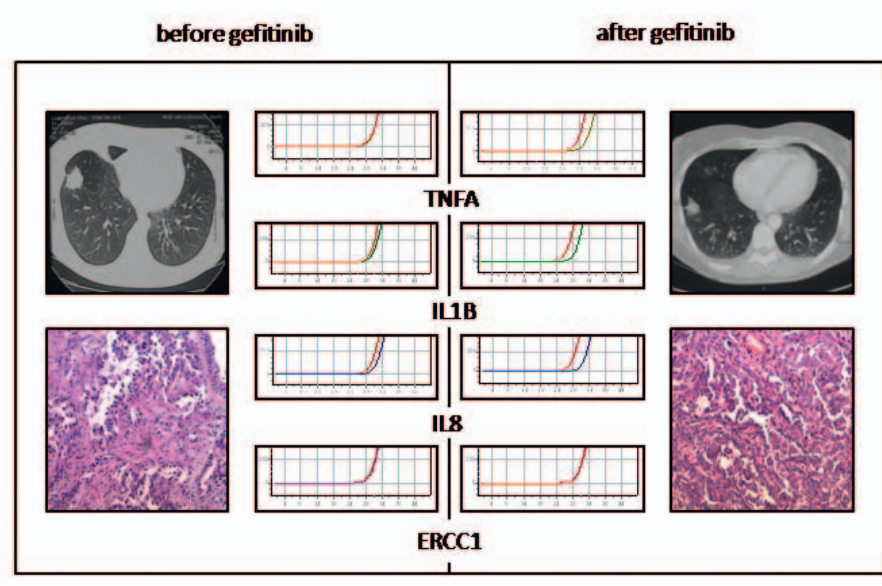

Fig. 1. Downregulation of inflammatory molecules in the EGFR-mutated lung adenocarcinoma treated by gefitinib. sion status was not changed significantly for ICAM1, DPD and ERCC1.

This study confirmed that EGFR inhibition may reduce the activity of several inflammation-related genes in vivo. This effect may contribute to the rapid symptomatic improvement observed upon EGFR TKI administration. It would be highly desirable to compare pre- and post-treatment tumor samples by RNA array profiling. Unfortunately, currently available transcriptomic technologies are not yet fully adjusted to dealing with micro-amounts of RNA and/or archived tissue samples.

\section{Acknowledgement}

This work was supported by the Russian Federation for Basic Research (10-04-00962, 10-04-00260, 11-04-00227), the Federal Agency for Science and Innovations (contract 16.512.11.2237), the Commission of the European Communities (grant PITN-GA-2009-238132), and the Government of Moscow (grant 15/11).

\section{Disclosure Statement}

The authors declare no conflict of interest.

Table 1. Real-time RT-PCR analysis of an EGFR-mutated lung cancer sample before and after gefitinib therapy

\begin{tabular}{|c|c|c|c|c|}
\hline \multirow[t]{2}{*}{ Gene } & \multirow[t]{2}{*}{ PCR primers } & \multicolumn{2}{|c|}{ Analyzed/referee mRNA ratio } & \multirow[t]{2}{*}{ Before/after therapy expression ratio } \\
\hline & & before therapy & after therapy & \\
\hline TNFA & $\begin{array}{l}\text { CACCACGCTCTTCTGCCT } \\
\text { TGACTGCCTGGGCCAGAG }\end{array}$ & 0.62 & 0.16 & 3.88 \\
\hline IL1B & $\begin{array}{l}\text { GAGAATGACCTGAGCACCT } \\
\text { CGTGCAGTTCAGTGATCGTA }\end{array}$ & 0.20 & 0.07 & 2.86 \\
\hline IL6 & $\begin{array}{l}\text { CTGAGAAAGGAGACATGTAAC } \\
\text { CACCAGGCAAGTCTCCTCAT }\end{array}$ & 0.00 & 0.01 & - \\
\hline IL8 & $\begin{array}{l}\text { GACATACTCCAAACCTTTCCA } \\
\text { GACAGAGCTCTCTTCCATCA }\end{array}$ & 0.70 & 0.14 & 5.00 \\
\hline ICAM1 & $\begin{array}{l}\text { GTGCTATTCAAACTGCCCTG } \\
\text { TGGCAGCGTAGGGTAAGGT }\end{array}$ & 0.29 & 0.37 & 0.78 \\
\hline ERCC1 & $\begin{array}{l}\text { CCTGCTTGTCCAGGTGGAT } \\
\text { GCTCCAGGCGAGGATCAAT }\end{array}$ & 0.70 & 0.75 & 0.93 \\
\hline DPD & $\begin{array}{l}\text { AAGCCAGGATACTCTCGATG } \\
\text { GCTGTCACTTGGCTCTCTG }\end{array}$ & 0.84 & 1.12 & 0.75 \\
\hline SDHA & $\begin{array}{l}\text { CCACTCGCTATTGCACACC } \\
\text { CACTCCCCGTTCTCCATCA }\end{array}$ & gene referee & & \\
\hline
\end{tabular}

\section{References}

1 Heist RS, Christiani D: EGFR-targeted therapies in lung cancer: predictors of response and toxicity. Pharmacogenomics 2009;10:59-68.

2 Moiseyenko VM, Procenko SA, Levchenko EV, Barchuk AS, Moiseyenko FV, Iyevleva AG, Mitiushkina NV, Togo AV, Semionov II, Ivantsov AO, Matsko DE, Imyanitov EN: High efficacy of first-line gefitinib in non-Asian patients with EGFR-mutated lung adenocarcinoma. Onkologie 2010;33:231-238.

-3 Bearz A, Vaccher E, Spazzapan S, Berretta M, Tirelli U: Gefitinib in patients with non-small cell lung cancer: symptomatic improvement within a few days. Lung Cancer 2005;49:417-418.

4 Gao SP, Mark KG, Leslie K, Pao W, Motoi N, Gerald WL, Travis WD, Bornmann W, Veach D,
Clarkson B, Bromberg JF: Mutations in the EGFR kinase domain mediate STAT3 activation via IL-6 production in human lung adenocarcinomas. J Clin Invest 2007;117:3846-3856.

5 Le Quément C, Guénon I, Gillon JY, Lagente V, Boichot E: MMP-12 induces IL-8/CXCL8 secretion through EGFR and ERK1/2 activation in epithelial cells. Am J Physiol Lung Cell Mol Physiol 2008;294:L1076-L1084.

6 Liu K, Gualano RC, Hibbs ML, Anderson GP, Bozinovski S: Epidermal growth factor receptor signaling to Erk1/2 and STATs control the intensity of the epithelial inflammatory responses to rhinovirus infection. J Biol Chem 2008;283:9977-9985. Stathopoulos GT, Kollintza A, Moschos C, Psallidas I, Sherrill TP, Pitsinos EN, Vassiliou S, Karatza
M, Papiris SA, Graf D, Orphanidou D, Light RW, Roussos C, Blackwell TS, Kalomenidis I: Tumor necrosis factor-alpha promotes malignant pleural effusion. Cancer Res 2007;67:9825-9834.

8 Landvik NE, Hart K, Skaug V, Stangeland LB, Haugen A, Zienolddiny S: A specific interleukin1B haplotype correlates with high levels of IL1B mRNA in the lung and increased risk of non-small cell lung cancer. Carcinogenesis 2009;30:1186-1192. Iyevleva AG, Buslov KG, Togo AV, Matsko DE, Filimonenko VP, Moiseyenko VM, Imyanitov EN: Measurement of DPD and TS transcripts aimed to predict clinical benefit from fluoropyrimidines: confirmation of the trend in Russian colorectal cancer series and caution regarding the gene referees. Onkologie 2007;30:295-300. 